\title{
Patterns of Brain Vasopressin Receptor Distribution Associated with Social Organization in Microtine Rodents
}

\author{
Thomas R. Insel, ${ }^{1}$ Zuo-Xin Wang, ${ }^{2}$ and Craig F. Ferris ${ }^{3}$ \\ 'Lab of Neurophysiólogy, NIMH, Poolesville, Maryland 20837, 'Department of Psychology, University of Massachusetts, \\ Amherst, Massachusetts 01003, and ${ }^{3}$ Department of Psychiatry, University of Massachusetts, Medical Center, Worcester, \\ Massachusetts 01655
}

\begin{abstract}
Central vasopressin pathways have been implicated in the mediation of paternal behavior, selective aggression, and affiliation in monogamous prairie voles. Here we demonstrate markedly different patterns of brain vasopressin receptor binding in the monogamous prairie vole and the congeneric nonmonogamous (promiscuous) montane vole. Vasopressin binding was assessed with both ${ }^{3} \mathrm{H}$-vasopressin and ${ }^{125} \mid$-sarc-AVP using receptor autoradiography. The specificity of binding was consistent with a $V_{\text {1a }}$ receptor, the saturation kinetics were similar in the two species, and neither species showed evidence of sexual dimorphisms. In the prairie vole, highest specific binding was observed in the accessory olfactory bulb, diagonal band, laterodorsal thalamus, and superior colliculus. In the montane vole, specific binding was observed in the accessory olfactory bulb and superior colliculus as well, but in several other regions with high levels of binding in the prairie vole, binding was low or undetectable in the montane vole. In this nonmonogamous species, specific binding was high in lateral septum. Functional studies demonstrated the induction of phosphoinositol by AVP in the septum of the montane vole but not in the prairie vole. The pattern of ${ }^{125} \mid$-sarc-AVP binding to lateral septum may reflect the social organization of these two species, as similar differences in AVP receptor distribution in the lateral septum were also observed in two related species, pine voles and meadow voles, which are monogamous and nonmonogamous, respectively. These results, along with earlier studies of AVP's effects on pair bonding, suggest the importance of this neuropeptide for the mediation of behaviors related to social organization.
\end{abstract}

[Key words: vasopressin, AVP, vole, septum, thalamus, phosphoinositol, monogamy]

Central administration of the neuropeptide arginine-vasopressin (AVP) has been associated with a variety of effects from enhanced learning to antipyresis (reviewed in de Wied et al., 1993). Onc cluster of central effects of AVP that has received recent attention might be best described as the facilitation of species-specific social behaviors. AVP in the golden hamster induces flank marking (Ferris et al., 1984), in the adult rat facilitates social memory (Dantzer et al., 1987), in the infant rat

\footnotetext{
Received Dec. 10, 1993; revised Feb. 25, 1994; accepted March 9, 1994.

Correspondence should be addressed to Thomas R. Insel, M.D., National Institute of Mental Health, P.O. Box 608, Poolesville, MD 20837.

Copyright (C) 1994 Society for Neuroscience 0270-6474/94/145381-12\$05.00/0
}

modulates the isolation call (Winslow and Insel, 1993), and in the squirrel monkey alters the behavioral response to social separation (Winslow and Insel, 1991a). Remarkably, many of the AVP effects on social behavior have been reported exclusively in males and appear androgen dependent (Bluthé et al., 1990; Winslow and Insel, 1991b; Ferris, 1992). Perhaps the most ambitious claims for AVP as a peptide facilitating male social behavior come from recent studies with a monogamous rodent, Microtus ochrogaster, the prairie vole. In the male of this species, AVP has been implicated in mate guarding, paternal behavior, and the development of a preference for one specific mate-all critical to the process of pair bonding that characterizes monogamous social organization (Winslow et al., 1993; Wang et al., in press).

If AVP were essential for the mediation of pair bonding, one might predict that neural circuits for this peptide would differ in monogamous and polygynous species, as pair bonding is observed in the former and not the latter. Voles of the genus Microtus display diverse patterns of social organization and may provide some useful comparisons in which to test this prediction. For instance, prairie voles and montane voles (M. montanus), two species that are similar in appearance and many aspects of nonsocial behavior, display marked differences in social affiliation (Shapiro and Dewsbury, 1990). In their natural habitat, prairie voles frequently form long-term monogamous relationships and show high levels of parental care (Dewsbury, 1981; Getz et al., 1981; Getz and Hofman, 1986). Even in the laboratory, adult prairie voles usually sit side by side with a mate, attack strange adults, and display intense maternal and paternal care (Oliveras and Novak, 1986; Carter et al., 1990; Shapiro and Dewsbury, 1990). In contrast, montane vole adults live in isolated burrows and show no evidence of monogamy (Jannett, 1980). In the laboratory, montane voles appear minimally parental and generally spend little time in contact with conspecifics (McGuire and Novak, 1986; Shapiro and Dewsbury, 1990). Species differences in social behavior are evident very early in life, as prairie vole young show marked increases in ultrasonic calls and glucocorticoid secretion in response to social isolation, whereas montane vole pups show little, if any, behavioral or physiologic response to separation from the nest (Shapiro and Insel, 1990). It appears that an inherent difference in the propensity for social contact or affiliation underlies the differences in social organization.

We have previously described species differences in the distribution of oxytocin receptors in prairie and montane voles (Insel and Shapiro, 1992). These differences were of interest 
because (1) related species selected for similar contrasts of social organization showed analogous differences in binding, (2) no species differences were detected for opiate or benzodiazepine receptors, and (3) in the montane vole female, the pattcrn of binding changed postpartum to resemble the pattern in the prairie vole, with the emergence of maternal behavior. In addition, oxytocin was found to facilitate selective affiliation in the female prairie vole (Williams et al., in press). The present study investigated the distribution of vasopressin receptors in both prairie and montane voles. To examine the coupling of prairie and montane vole receptors to a second-messenger system, regional induction of phosphoinositol by vasopressin was measured in both species. Finally, to examine if species differences in receptor distribution were related to patterns of social organization, the comparison of receptor binding was extended to two other congeneric species, pine and meadow voles, which are believed to be monogamous and nonmonogamous, respectively.

\section{Materials and Methods}

Animals. Both male and female prairie and montane voles from the $\mathrm{NIH}$ breeding colonies in Poolesville, MD, were studied. Male pine and meadow voles were obtained from the breeding colonies of the University of Massachusetts Department of Zoology. All animals were weaned at $21 \mathrm{~d}$ of age and housed with same-sex littermates until 60$90 \mathrm{~d}$ of age, when they were used for autoradiographic experiments. All animals were sexually inexperienced. Housing was on a 12:12 light:dark schedule with food and water available ad libitum.

Receptor autoradiography. Following decapitation, brains were quickly removed, frozen on dry ice, and stored at $-70^{\circ} \mathrm{C}$ until sectioned. Cryostat-cut $20 \mu \mathrm{m}$ slide-mounted sections (at $120 \mu \mathrm{m}$ intervals) were used for the receptor binding assay. Two ligands were used. Initial studies employed ${ }^{3} \mathrm{H}$-AVP (from New England Nuclear-Dupont, Boston, MA); subsequent studies used ${ }^{125}$ I-sarc-AVP, a selective, high-affinity $\mathrm{V}_{1 \mathrm{a}}$ receptor antagonist previously characterized in rat and hamster brain sections (Phillips et al., 1988; Ferris et al., 1993).

For ${ }^{3} \mathrm{H}$-AVP binding, sections were preincubated for $10 \mathrm{~min}$ in 50 $\mu \mathrm{M}$ GTP in Tris- $\mathrm{HCl}$ buffer with $100 \mathrm{~mm} \mathrm{NaCl}$ to remove endogenous ligand, and then washed twice for $10 \mathrm{~min}$ in Tris- $\mathrm{HCl}$ buffer to remove $\mathrm{NaCl}$ and GTP. Sections were then placed in incubation buffer consisting of $50 \mathrm{~mm}$ Tris- $\mathrm{HCl}(\mathrm{pH} 7.4)$ with $10 \mathrm{~mm} \mathrm{MgCl}, 0.1 \% \mathrm{BSA}, 0.05 \%$ bacitracin for $90 \mathrm{~min}$ at $24^{\circ} \mathrm{C}$ containing $5 \mathrm{nM}{ }^{3} \mathrm{H}$-AVP. In adjacent sections, $0.5 \mu \mathrm{M}$ unlabeled AVP was added to the incubation buffer to define nonspecific binding. Following incubation, all sections were washed twice for $4 \mathrm{~min}$ in $50 \mathrm{mM}$ Tris- $\mathrm{HCl}$ with $10 \mathrm{mM} \mathrm{MgCl}_{2}$ at $4^{\circ} \mathrm{C}$, and then immediately dried under a stream of cool air.

For ${ }^{125} \mathrm{I}$-sarc-AVP binding, sections were preincubated for $5 \mathrm{~min}$ in $50 \mu \mathrm{M}$ GTP in $100 \mathrm{~mm} \mathrm{NaCl}$ (this step was eliminated from later studies without affecting the results) followed by $2 \times 5$ min rinses in Tris- $\mathrm{HCl}$ (pH 7.4). Incubation buffer was the same as described above for ${ }^{3} \mathrm{H}$ AVP. For ${ }^{125}$ I-sarc-AVP, incubation lasted $60-75 \mathrm{~min}$ and a tracer concentration of 30-50 pM was used. In initial studies it was found that nonspecific binding (i.e., background label) with this ligand was high but reversible with extensive washes. The following wash protocol was found to minimize the nonspecific binding without reducing the specific binding of ${ }^{125}$ I-sarc-AVP: dip in incubation buffer to remove excess tracer, $4 \mathrm{~min}$ in $0.1 \%$ paraformaldehyde (to preserve tissue integrity) in Tris- $\mathrm{HCl}$ with $10 \mathrm{~mm} \mathrm{MgCl}, 4-6 \times 4 \mathrm{~min}$ in Tris- $\mathrm{HCl}$ with $10 \mathrm{~mm}$ $\mathrm{MgCl}_{2}$ buffer, 4 min in same buffer diluted $1: 1$ with D.I. $\mathrm{H}_{2} \mathrm{O}$, dip in D.I. $\mathrm{H}_{2} \mathrm{O}$ (to remove buffer salts). All washes were performed at $4^{\circ} \mathrm{C}$ and followed immediately by drying under stream of cool air. Nonspecific binding was defined by incubating adjacent sections with approximately $0.5 \mu \mathrm{M}$ [ 1 - $(\beta$-mercapto- $\beta, \beta$-cyclopentamethylene propionic acid),2-( $O$-methyl)tyrosine]-Arg ${ }^{8}-\mathrm{AVP}-\mathrm{a}$ selective $\mathrm{V}_{\mathrm{la}}$ ligand (Kruszynski et al., 1980), here referred to as $\mathrm{d}\left(\mathrm{CH}_{2}\right)_{5}[\mathrm{Tyr}(\mathrm{Me})] \mathrm{AVP}$.

When dry, slides were apposed to Hyperfilm (Amersham, Arlington Heights, IL) along with ${ }^{125} \mathrm{I}$ plastic standards (Amersham) for $2-3 \mathrm{~d}$ ( ${ }^{125} \mathrm{I}$ sarc-AVP) or ${ }^{3} \mathrm{H}$ plastic standards for 12 weeks $\left({ }^{3} \mathrm{H}-\mathrm{AVP}\right)$. The resulting autoradiograms were analyzed with the IMAGE program for the Macintosh, permitting the conversion of optical density to dpm/tissue equivalents using a third-order polynomial regression. Nonspecific binding was subtracted from total binding to yield values for specific binding.
Based on previous experience comparing optical density quantification to binding values obtained in homogenate assays with other iodinated ligands, we recommend that the absolute values obtained as $\mathrm{dpm} /$ tissue equivalent be treated as relative numbers for comparison within an experiment.

Saturation and competition studies. In previous studies with rat and hamster, ${ }^{125}$ I-sarc-AVP appeared to bind specifically to a vasopressin rather than an oxytocin receptor, as AVP was roughly 1000 times more potent than oxytocin for displacing ${ }^{125}$ I-sarc-AVP binding in brain sections (Phillips et al., 1988; Ferris et al., 1993). To compare the specificity of ${ }^{125} \mathrm{I}$-sarc-AVP binding in prairie and montane voles, 20 adjacent 10 $\mu \mathrm{m}$ sections through the laterodorsal thalamus (prairie vole) and the lateral septum (montane vole) were exposed to ${ }^{125} I$-sarc- $\Lambda$ VP using the binding protocol described above. In each region, the first and last sections were compared to ensure consistent binding along the $200 \mu \mathrm{m}$ in the rostral-caudal plane. Specificity of ${ }^{125} \mathrm{I}$-sarc-AVP binding (70 pM) was determined in competition studies using nine concentrations of the selective $\mathrm{V}_{1 \mathrm{a}}$ ligand $\mathrm{d}\left(\mathrm{CH}_{2}\right)_{5}[\mathrm{Tyr}(\mathrm{Me})] \mathrm{AVP}$ ranging from $10^{-12}$ to $10^{-6}$ or five concentrations of $\mathrm{Thr}^{4} \mathrm{Gly}^{7} \mathrm{OT}$ (oxytocin) and $\left[\mathrm{d}\left(\mathrm{CH}_{2}\right) 5, \mathrm{D}\right.$ $\mathrm{Phe}^{2}, \mathrm{Ile}^{4}, \mathrm{Ala}^{9}-\mathrm{NH}_{2}$ ]-AVP $\left(\mathrm{V}_{2}\right)$ ranging from $10^{-9}$ to $10^{-6}$. Each of these studies compared adjacent sections from a single animal with three to four animals used for each displacer. Displacer peptides were obtained from Peninsula (Burlingame, CA).

A similar strategy was used to investigate the saturation kinetics of ${ }^{125}$ I-sarc-AVP binding in 20 adjacent $10 \mu \mathrm{m}$ sections through the laterodorsal thalamus (prairie vole) and the lateral septum (montane vole). For each species, sections from three or four animals were cxposcd to 1 of 10 concentrations of ${ }^{125}$ I-sarc-AVP, ranging from 2 to $1000 \mathrm{pM}$. Both species were represented in every study. At each concentration, blanks were generated by adding $1 \mu \mathrm{M} \mathrm{d}\left(\mathrm{CH}_{2}\right)_{5}[\mathrm{Tyr}(\mathrm{Me})] A V P$. To facilitate image analysis, slides exposed to the highest concentrations of ${ }^{125} \mathrm{I}$-sarc-AVP were exposed to film for $24 \mathrm{hr}$, while lower concentrations received either 5,7 , or 12 d exposures. Once again, the reader is cautioned against overinterpreting the numbers resulting from image analysis, particularly because sections were $10 \mu \mathrm{m}$ thick whereas $20 \mu \mathrm{m}$ standards were used for converting optical density to $\mathrm{dpm} / \mathrm{mg}$ tissue equivalent.

Iodination of sarc- $A V P$. As previously described, synthetic sarc-AVP was iodinated through reaction with chloramine-T (Ferris et al., 1993). Sarc-AVP $(4 \mu \mathrm{g})$ and $0.5 \mathrm{mCi}$ of $\mathrm{Na}^{125} \mathrm{I}$ were mixed in $50 \mu \mathrm{l}$ of phosphate buffer $(0.5 \mathrm{M}, \mathrm{pH} 7.5)$. The reaction was initiated by the addition of 40 $\mu$ l of chloramine-T $(0.2 \mathrm{mg} / \mathrm{ml}$ in 0.5 phosphate buffer; Sigma Chemical). After mixing, $0.5 \mathrm{ml}$ of $0.1 \%$ bovine serum albumin (in phosphate buffer) was added. The ${ }^{125}$ I-sarc-AVP was purified by high-pressure liquid chromatography using a Bondapak C-18 column $(3.9 \times 300 \mathrm{~mm})$ equilibrated at $1.5 \mathrm{ml} / \mathrm{min}$ with $0.1 \%$ trifluoroacetic acid (TFA). Two minutes after sample injection, a 60 min linear gradient was run to $40 \%$ acetonitrile in $0.1 \%$ TFA. Fractions $(1.5 \mathrm{ml})$ were collected every minute from the time of injection. The major peak of monoiodinated sarc-AVP appeared in fractions $47-48$, while a smaller peak of diiodinated peptide appeared in fractions 51-52. Fractions $47-48$ were diluted in $0.1 \mathrm{M}$ acetic acid with $0.1 \%$ bovine serum albumin and stored at $-80^{\circ} \mathrm{C}$. Specific activity was approximately $2400 \mathrm{Ci} / \mu \mathrm{g}$ of peptide. Unlabeled sarc-AVP was generously provided by Prof. Z. Grzonka (University of Gdansk, Gdansk, Poland).

Phosphoinositol hydrolysis. To determine if receptors in both species were functionally coupled to the phosphoinositol-diacylglycerol cycle, we measured the generation of phosphoinositol following AVP incubation with tissue slices. Male prairie and montane voles were decapitated and brains were rapidly dissected to harvest the septum, dorsal thalamus, and corpora quadrigemina. Dissected tissue was immediately placed into ice-cold, freshly oxygenated $\left(95 \% \mathrm{O}_{2}, 5 \% \mathrm{CO}_{2}\right)$ buffer containing (mM) $118.0 \mathrm{NaCl}, 4.8 \mathrm{KCl}, 1.3 \mathrm{CaCl}_{2}, 1.2 \mathrm{MgSO}_{4}, 5.0 \mathrm{MgCl}_{2}$, $1.2 \mathrm{KH}_{2} \mathrm{PO}_{4}, 11.0$ glucose, $25.0 \mathrm{NaHCO}_{3}$ (final $\mathrm{pH}$ adjusted to 7.4 with $0.1 N \mathrm{HCl}$ ). Tissue was cross-chopped at $0.35 \mathrm{~mm}$ interval with a McIlwain tissue chopper (Brinkman, Westburg, NY). The slices were equilibrated in $25 \mathrm{ml}$ of buffer with $\mathrm{O}_{2} / \mathrm{CO}_{2}$ by bubbling for $45 \mathrm{~min}$ at $37^{\circ} \mathrm{C}$ with one intermediate change of buffer. After equilibration, the buffer was removed by aspiration and $0.3 \mu \mathrm{M}{ }^{3} \mathrm{H}$-inositol was added for $1 \mathrm{hr}$ with continuous $\mathrm{O}_{2} / \mathrm{CO}_{2}$ perfusion and dispersion of slices with a Pasteur pipette every $15 \mathrm{~min}$. Following incubation with tracer, slices were washed three times with $15 \mathrm{ml}$ of buffer and then $40 \mu \mathrm{l}$ of gravitypacked slices was pipetted into $4 \mathrm{ml}$ vials containing $10 \mathrm{~mm} \mathrm{LiCl}$. Following preincubation with $\mathrm{LiCl}$ for $20 \mathrm{~min}$ in $\mathrm{O}_{2} / \mathrm{CO}_{2}$ atmosphere, vehicle (buffer) or agonist ( 0.5 or $5.0 \mu \mathrm{g}$ AVP) was added to each tube. 

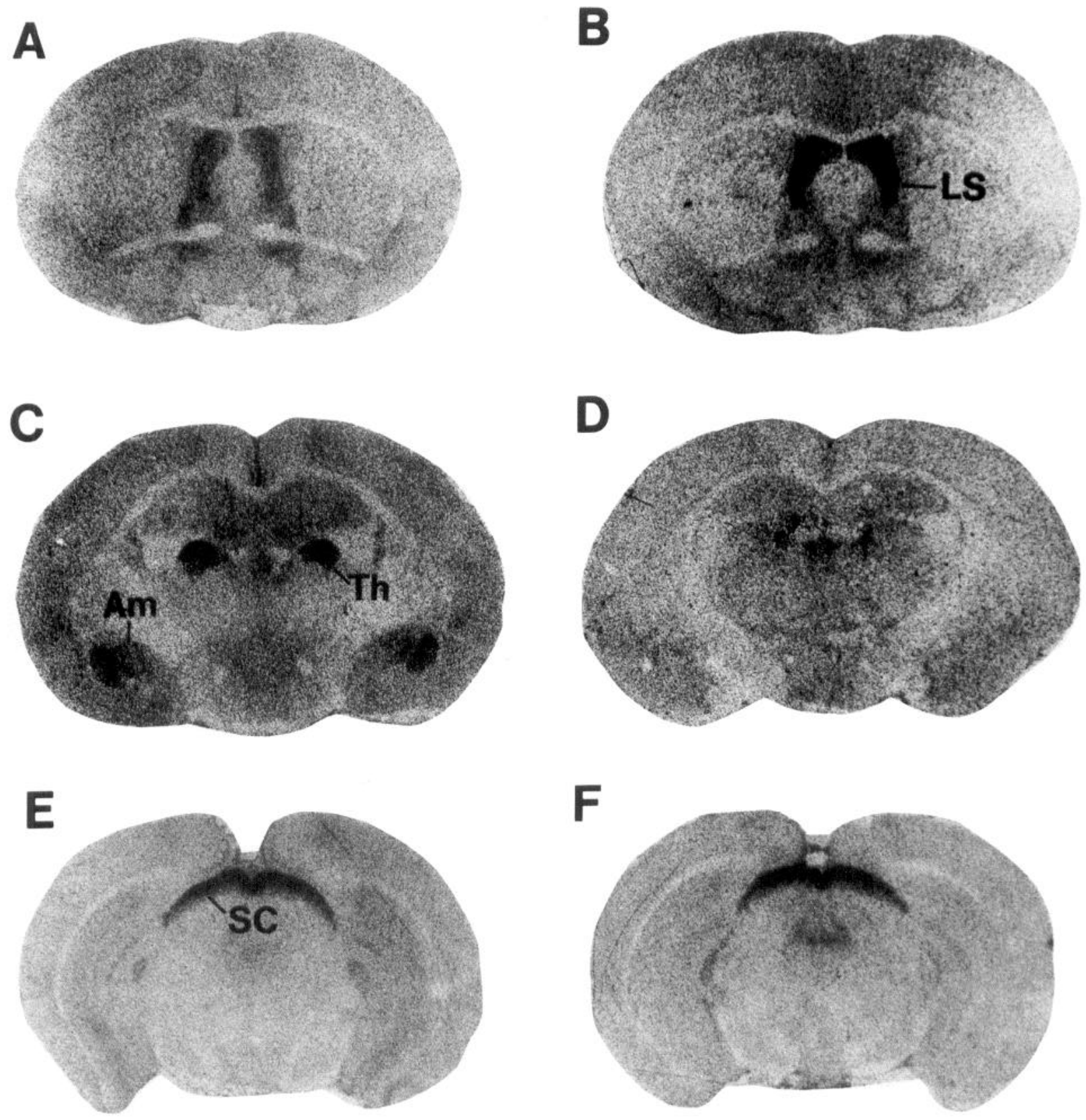

Figure 1. Binding of ${ }^{3} \mathrm{H}-\mathrm{AVP}$ in prairie and montane voles. Pattern of ${ }^{3} \mathrm{H}-\mathrm{AVP}$ binding is shown in bright-field images from prairie vole $(A, C$, and $E$ ) and montane vole $(B, D$, and $F)$. Quantification is provided in Table 1 . Note increased binding to dorsolateral septum $(L S)$ in montane vole and binding to laterodorsal thalamus $(T h)$ and both central and basolateral nuclei of amygdala $(A m)$ in prairie vole. Both species show binding to superior colliculus $(S C)$. ${ }^{3} \mathrm{H}$-AVP is not an ideal ligand-it binds with relatively low affinity to AVP receptors and binds with slightly lower affinity to oxytocin receptors. Therefore, the patterns of binding observed here cannot be unambiguously attributed to AVP receptors.

Following a 45 min incubation in $\mathrm{O}_{2} / \mathrm{CO}_{2}$ atmosphere at $37^{\circ} \mathrm{C}$, the reaction was terminated by the addition of $\mathrm{CHCl}_{3}: \mathrm{MeOH}(1: 2)$. The samples were vortexed vigorously and centrifuged at $3000 \mathrm{rpm}$ for 5 $\min$ at $4^{\circ} \mathrm{C}$, and $1 \mathrm{ml}$ of the aqueous phase was applied to a Dowex-1Resin column. ${ }^{3} \mathrm{H}-\mathrm{IP}$, was eluted with $5 \mathrm{ml}$ of $0.2 \mathrm{M}$ ammonium formate/ $0.1 \mathrm{~N}$ formic acid. Samples were corrected for tissue volume with counts from the dried organic phase. All samples were run in triplicate, with 10 male sexually naive voles used for each species in each experiment. Each experiment included both species and was replicated twice (total of 30 voles for each species).

Data analysis. For autoradiographic studies, all slides from a given region were processed simultaneously with each run, including at least three males and three females of each species for ${ }^{3} \mathrm{H}-\mathrm{AVP}$. Analysis by region included a two-way ANOVA with main factors of species and gender. For ${ }^{125}{ }^{2}$-sarc-AVP binding, four or five males of each species were compared. Sections from females ( $n=3$ for each species) were run independently. Anatomic regions were defined from stained slides, with anatomic boundaries adopted from Paxinos and Watson (1986). Generally, three sections were measured in each individual for each region to provide an individual mean value. Differences at the $p=0.05$ level were considered significant.

\section{Results}

Distribution of ${ }^{3} \mathrm{H}-\mathrm{AVP}$ binding

Specific binding of ${ }^{3} \mathrm{H}-\mathrm{AVP}$ was found in several regions in both species (Fig. 1). As shown in Table 1, prairie voles had higher levels of ${ }^{3} \mathrm{H}$-AVP binding in the laterodorsal thalamus and amygdala (both central and basolateral nuclei), whereas mon- 
Table 1. ${ }^{3} \mathrm{H}-\mathrm{AVP}$ binding in prairie and montane voles

\begin{tabular}{llccl} 
Region & Prairie vole & Montane vole & $F$ (species) & $\begin{array}{l}F \\
\text { (gender) }\end{array}$ \\
\hline Lateral septum & $2044 \pm 271$ & $6137 \pm 443$ & $237.9^{*}$ & 1.5 \\
Laterodorsal thalamus & $1767 \pm 469$ & $261 \pm 97$ & $16.2^{*}$ & 5.2 \\
Basolateral amygdala & $1770 \pm 236$ & $492 \pm 92$ & $24.8^{*}$ & 1.7 \\
Superior colliculus & $2967 \pm 623$ & $2381 \pm 319$ & 0.9 & 2.5 \\
\hline
\end{tabular}

Values represent mean \pm SEM dpm/mg tissue equivalent from six voles of each species.

${ }^{*} p<0.01$ for main effects by two-factor (gender $\times$ species) ANOVA.

tane voles had much higher levels of ${ }^{3} \mathrm{H}$-AVP binding in the lateral septum. ${ }^{3} \mathrm{H}-\mathrm{AVP}$ binding to superior colliculus was high in both species. There were no overall effects of gender on ${ }^{3} \mathrm{H}$ AVP binding in any of the regions examined. Nonspecific binding was high but homogeneous in both species (nonspecific binding $=2331 \pm 365 \mathrm{dpm} / \mathrm{mg}$ tissue equivalent), representing roughly half of total binding in an area labeled in both species, such as the superior colliculus.

\section{Distribution of ${ }^{125}$ I-sarc-AVP binding}

With ${ }^{125}$ I-sarc-AVP, several regions that were not detected with ${ }^{3} \mathrm{H}$-AVP binding appeared to show clear specific binding (Table 1). Nonspecific binding was lower than observed for ${ }^{3} \mathrm{H}-\mathrm{AVP}$ and was consistently homogeneous across sections. In the forebrain, mean $( \pm$ SEM) binding in the presence of an excess of the $\mathrm{V}_{1}$ displacer was $1561 \pm 195 \mathrm{dpm} / \mathrm{mg}$ tissue equivalent for the prairie vole $(n=5)$ and $938 \pm 167 \mathrm{dpm} / \mathrm{mg}$ tissue equivalent for the montane vole $(n=5)$. These values represent $7.7 \%$ and $7.0 \%$ of total binding in the superior colliculus in prairie and montane voles, respectively.

Beginning with the most rostral sections in the prairie vole (Fig. 2), specific binding was high in the accessory olfactory bulb including the adjacent granule cell layer. In the main olfactory bulb, modest binding was observed in the internal granular layer with an inconsistent beaded appearance in the outer part of this layer. Although this latter pattern could be specific to the mitral
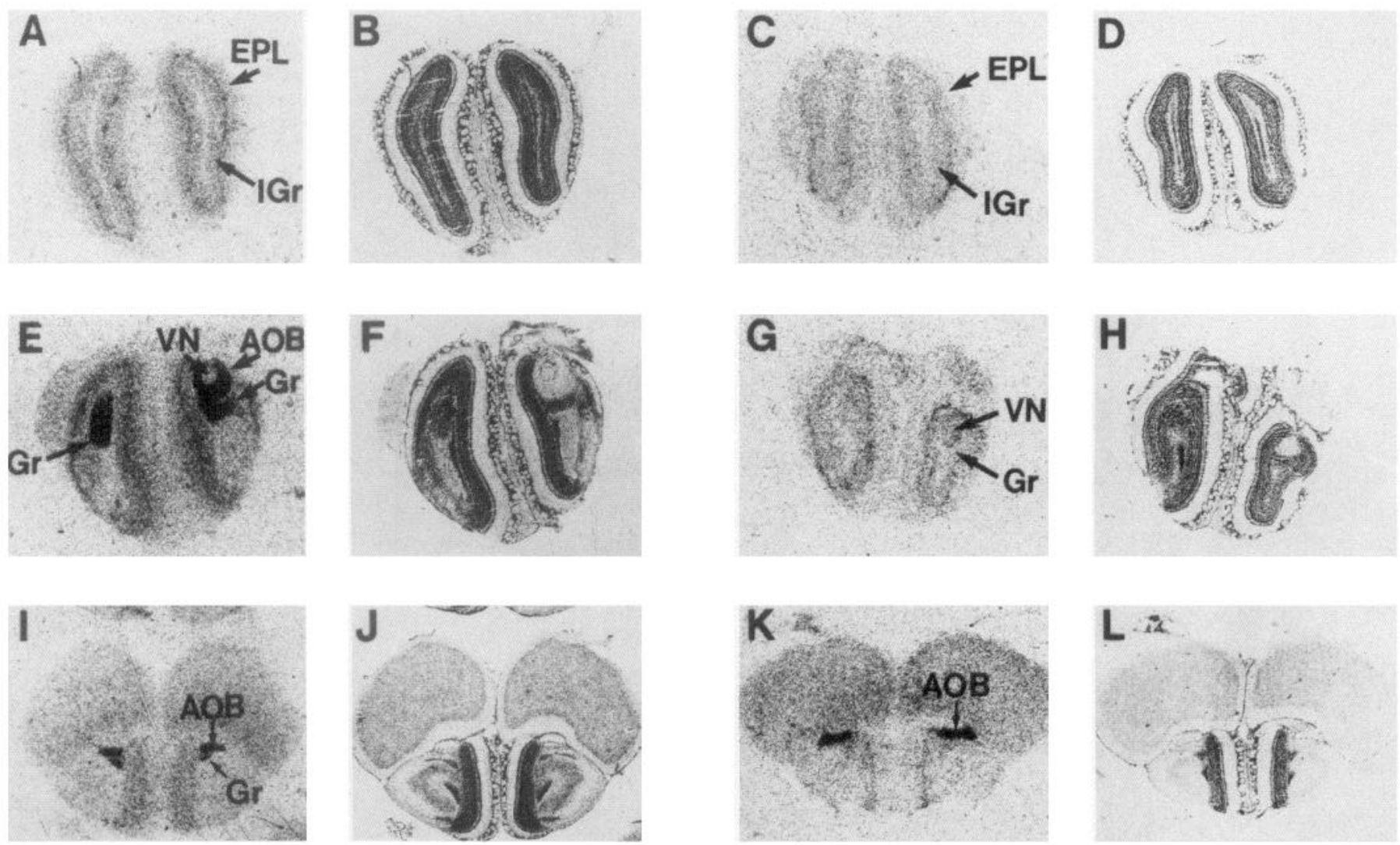

Figure 2. Binding of ${ }^{125} \mathrm{I}$-sarc-AVP to olfactory bulb in prairie and montane voles. Bright-field images of ${ }^{125}$ I-sarc-AVP binding to olfactory bulb in prairie voles $(A, E$, and $I)$ and montane voles $(C, G$, and $K)$ are shown adjacent to Nissl-stained sections $(B, F$, and $J$ for prairie vole; $D$, $H$, and $L$ for montane vole). In both species there is modest binding in the internal granular layer (IGr), with local foci detected in the outer margin, possibly indicating binding to the mitral cell layer $(A$ and $C)$. Specific binding could not be detected consistently in the external plexiform layer $(E P L)$ of either species. In the prairie vole, but not the montane vole, there is intense binding to the accessory olfactory bulb $(A O B)$, including the granule cell layer $(G r)$, but not the vomeronasal nerve $(V N)(E$ and $G)$. In the montane vole, binding is detectable in the more posterior part of the $\mathrm{AOB}(K)$, although not in the granule cell layer. 

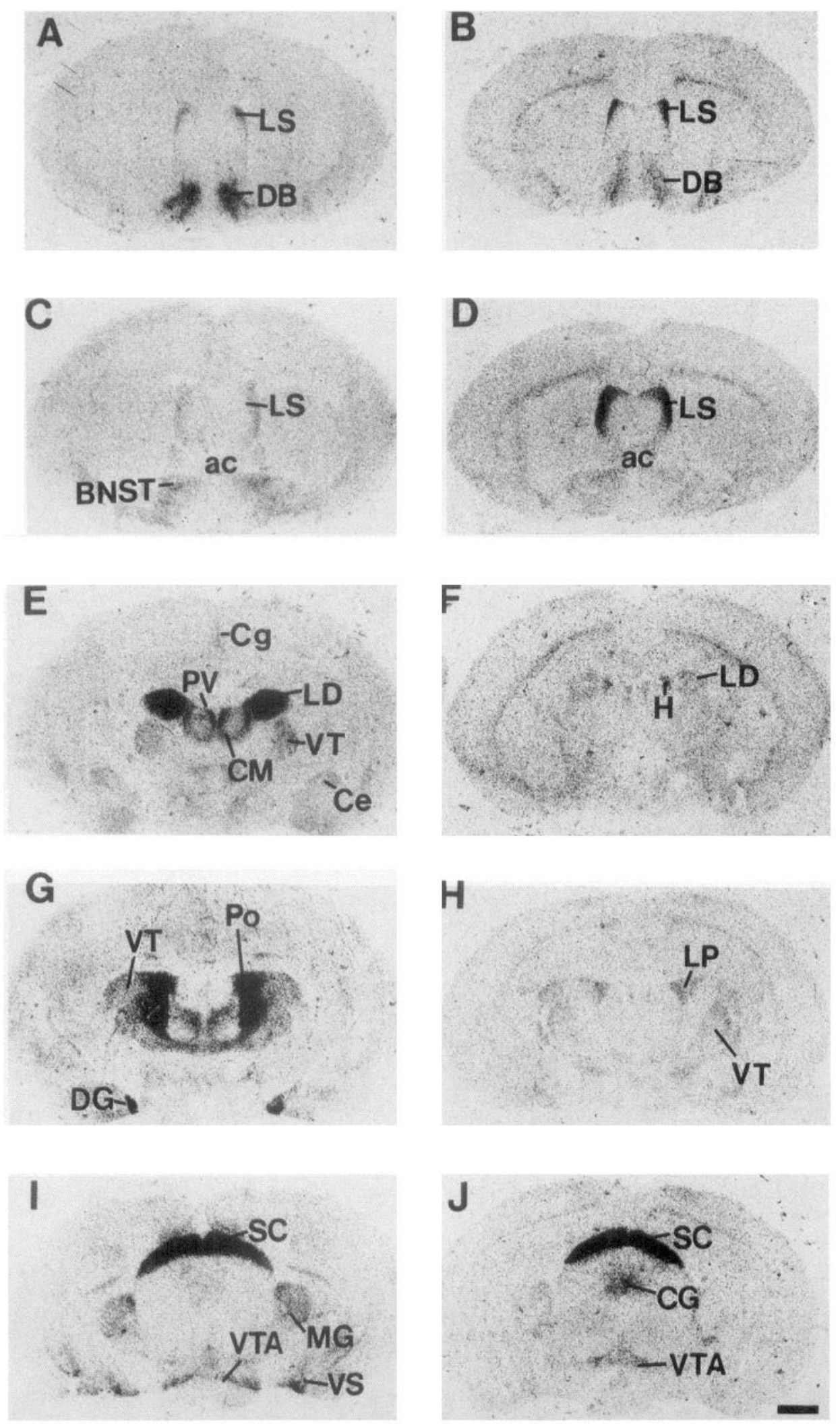

Figure 3. Binding of ${ }^{125} \mathrm{I}$-sarc-AVP to forebrain and midbrain in prairie and montane voles. Bright-field images of ${ }^{125}$ I-sarc-AVP binding to coronal sections through prairie vole $(A, C, E, G$, and $I)$ and montane vole $(B, D, F, H$, and $J$ ) are shown. Abbreviations are given in Table 2 (except for $a c$, anterior commissure), where quantitative values appear statistically different in virtually every region except for superior colliculus $(S C)$. Scale bar, $1.0 \mathrm{~mm}$. cell layer, we were unable to determine this precisely with either film or emulsion autoradiography. In contrast to the pattern of oxytocin receptors in the prairie vole (Witt et al., 1991), no specific binding was evident in the main olfactory nuclei with ${ }^{125}$ I-sarc-AVP. In the ventral forebrain (Fig. 3), specific binding was evident throughout the descending arms and horizontal limb of the diagonal band and in the ventral rostral division of the bed nucleus of the stria terminalis. Binding was not observed in medial preoptic area and only light label was evident in the lateral septum, mostly in the rostral dorsal division with the 

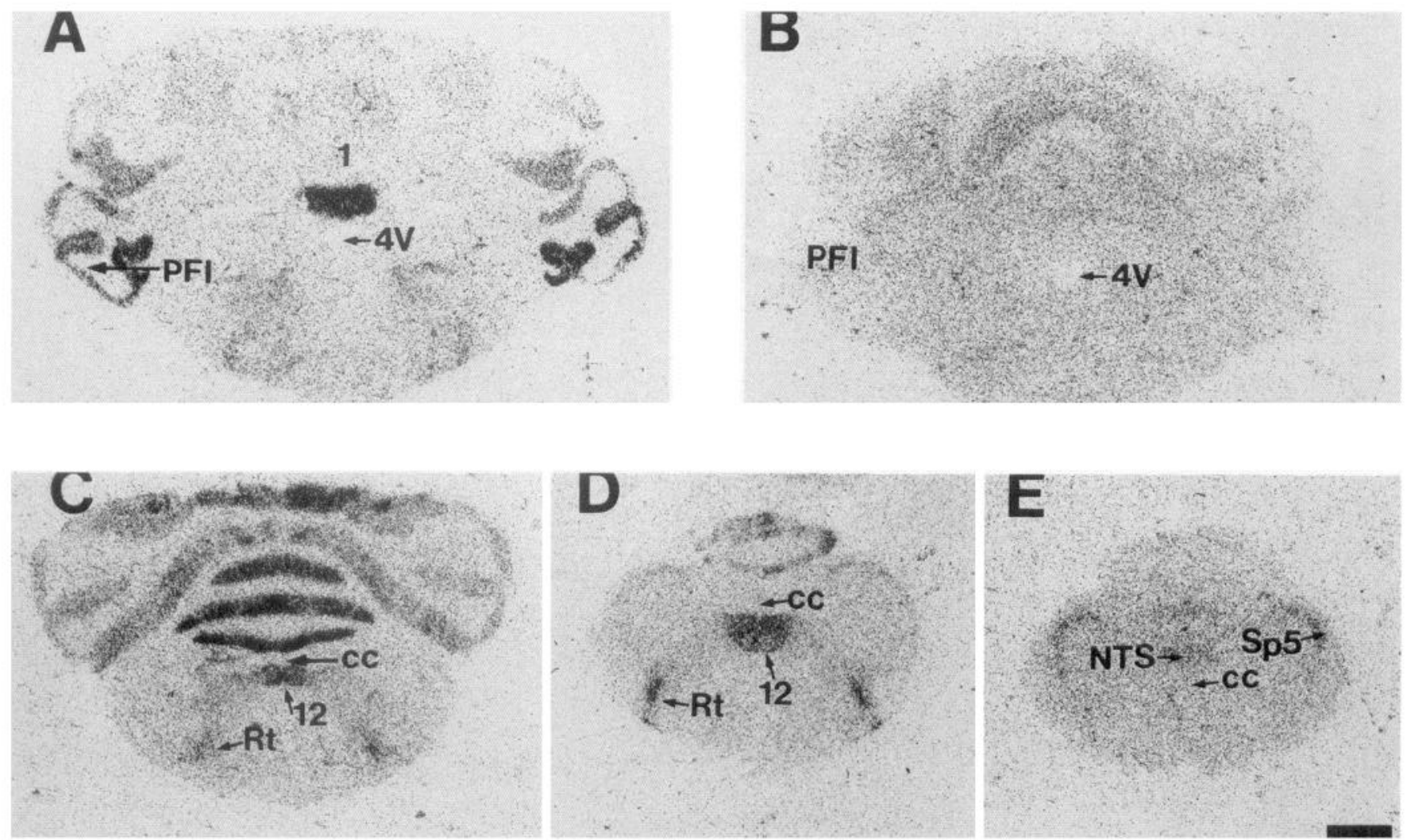

Figure 4. Binding of ${ }^{125}$ I-sarc-AVP to brainstem in prairie and montane voles. In contrast to forebrain pattern, in which prairie voles generally show more ${ }^{125} \mathrm{I}$-sarc-AVP binding than montane voles, in the brainstem and cerebellum it is the montane vole that shows more intense labeling. $A, C$, and $D$ show the pattern of ${ }^{125}$ I-sarc-AVP binding in montane vole, with label most intense in first lobule of cerebellum $(I)$ and in paraflocculus $(\mathrm{PFl})$ molecular layer. In addition, binding can be seen throughout the extent of the hypoglossal nucleus (12) and in the reticular nucleus $(R t)$ at the level of the nucleus ambiguus. In the prairie vole, specific binding was undetectable in the cerebellum or pons $(B)$, although low levels of label could be discerned in the medulla $(E)$ through the spinal tract of $\mathrm{V}(S p 5)$ and in the nucleus of the solitary tract $(N T S)$. Scale bar, $1.0 \mathrm{~mm}$.

ventral division [a site of dense staining for AVP terminals in the male prairie vole (Bamshad et al., 1993)] conspicuously unlabeled. Several thalamic nuclei showed intense specific binding in most (but not all) animals, particularly the laterodorsal and paraventricular, but also the centromedial, posterior, and ventral posterior nuclei. Moderate levels of binding were consistently found in the medial geniculate. In contrast to the pattern observed in the rat, guinea pig, and hamster (Phillips et al., 1988; Dubois-Dauphin et al., 1990; Tribollet et al., 1992; Ferris et al., 1993), there was no evidence of specific binding in the hippocampus or neocortex, except in three highly localized regions: intense binding was observed in the most posterior tip of the dentate gyrus at the ventral surface of the brain; light, diffuse label was evident in the ventral subiculum; and fine stippled label was found deep in the cingulate cortex at the rostral-caudal level of the thalamus. Only very modest binding was observed in the amygdala (note contrast to Fig. 1), exclusively in the central nucleus. In the midbrain, we found intense binding in the superior colliculus and faint label in the ventral tegmental area near the supramammillary nucleus. In the brainstem (Fig. 4), there was faint but consistent binding in the nucleus of the solitary tract and in the spinal tract of $\mathrm{V}$, but no other detectable specific binding was notable in the prairie vole.

In the montane vole, specific binding of ${ }^{125} \mathrm{I}$-sarc-AVP was just as high as the prairie vole in the main and accessory olfactory bulbs and superior colliculus, but in virtually all other regions there was a markedly different pattern of label (Figs. 24). Even within these regions, subtle species differences were apparent. For instance, the granule cell layer of the accessory olfactory bulb that was labeled in the prairie vole showed much less specific binding in the montane vole. In the diagonal band, bed nucleus of the stria terminalis, and most thalamic nuclei specific binding was significantly less in the montane vole. However, in a few discrete regions, ${ }^{125} \mathrm{I}$-sarc-AVP binding was greater in this species. This species difference was most evident in the lateral septum, especially the intermediate division, in which binding was approximately fourfold greater in the montane vole. Specific binding of ${ }^{125} \mathrm{I}$-sarc-AVP was also greater in the montane vole in one fine point of the lateral habenula, in the ventral subiculum, and in the central gray. In the brainstem, where binding was unremarkable in the prairie vole, several nuclei were labeled in the montane vole. The highest density of binding was found throughout the nucleus of the 12 th nerve, including the prepositus division. Specific binding of ${ }^{125} \mathrm{I}$-sarc-AVP was also observed in the reticular nucleus at the level of the nucleus ambiguus and in specific regions of the cerebellum, especially in the paraflocculus. Binding in the cerebellum was entirely restricted to the molecular layer.

No sex differences were found with ${ }^{125} \mathrm{I}$-sarc-AVP binding in either species. Three females of each species were compared to three males of each species in a separate experiment with equivalent results to those shown in Table 2 (data not shown). 


\begin{tabular}{|c|c|c|c|}
\hline Region & Abbrev. & Prairie & Montane \\
\hline \multicolumn{4}{|l|}{ Olfactory (main and accessory) } \\
\hline Internal granular layer & IGL & $1276 \pm 98$ & $1210 \pm 102$ \\
\hline External plex. layer & EPL & ND & ND \\
\hline Ant. olf. nucleus & AOP & $681 \pm 319$ & $475 \pm 71$ \\
\hline Vomeronasal nerve & VN & ND & ND \\
\hline Granule cell layer (accessory) & $\mathrm{Gr}$ & $4538 \pm 193$ & $1131 \pm 192^{* *}$ \\
\hline Accessory olf. bulb & AOB & $4919 \pm 567$ & $5508 \pm 1056$ \\
\hline \multicolumn{4}{|l|}{ Forebrain and midbrain } \\
\hline Diagonal band & $\mathrm{DB}$ & $5576 \pm 586$ & $1388 \pm 418^{* *}$ \\
\hline Nuc. accumbens & NAcc & $452 \pm 81$ & $548 \pm 295$ \\
\hline Lateral septum & LS & $1510 \pm 166$ & $5785 \pm 810^{* *}$ \\
\hline Bed nuc. stria term. (ventral) & BNST & $3441 \pm 571$ & $906 \pm 287^{* *}$ \\
\hline Cingulate cortex & $\mathrm{Cg}$ & $1678 \pm 690$ & $281 \pm 200^{*}$ \\
\hline Ventral subiculum & VS & $657.2 \pm 203$ & $1934 \pm 332^{* *}$ \\
\hline Dentate gyrus (post.) & $\mathrm{DG}$ & $3140 \pm 847$ & $70 \pm 47^{* *}$ \\
\hline Amygdala (central nuc.) & $\mathrm{Ce}$ & $1359 \pm 391$ & $315 \pm 105^{*}$ \\
\hline Habenula (lateral) & $\mathrm{H}$ & $815 \pm 342$ & $2516 \pm 910^{*}$ \\
\hline Thalamus (laterodorsal) & LD & $11,234 \pm 1665$ & $945 \pm 331^{* *}$ \\
\hline Thalamus (centromedial) & $\mathrm{CM}$ & $3489 \pm 310$ & $859 \pm 327^{* *}$ \\
\hline Thalamus (paraventricular) & PV & $4193 \pm 1153$ & $\mathrm{ND}^{* *}$ \\
\hline Thalamus (ventral posterolat.) & VT & $1760 \pm 313$ & $2025 \pm 985$ \\
\hline Thalamus (posterior) & Po & $5383 \pm 1060$ & $644 \pm 446^{* *}$ \\
\hline Medial geniculate & MG & $2538 \pm 214$ & $598 \pm 198^{* *}$ \\
\hline Superior colliculus & $\mathrm{SC}$ & $10,550 \pm 705$ & $12,417 \pm 562$ \\
\hline Ventral tegmental area & VTA & $542 \pm 184$ & $379 \pm 153$ \\
\hline Central gray & CG & $469 \pm 147$ & $2085 \pm 497^{* *}$ \\
\hline \multicolumn{4}{|l|}{ Brainstem and cerebellum } \\
\hline Reticular nucleus & $\mathbf{R t}$ & $601 \pm 173$ & $2944 \pm 380^{* *}$ \\
\hline Hypoglossal nucleus & 12 & ND & $4780 \pm 698^{* *}$ \\
\hline Nucleus of solitary tract & NTS & $1867 \pm 385$ & $\mathrm{ND}^{* *}$ \\
\hline Spinal tract of $\mathrm{V}$ & Sp5 & $1529 \pm 312$ & $134 \pm 61^{* *}$ \\
\hline Paraflocculus & PFI & ND & $1648 \pm 247^{* *}$ \\
\hline Cerebellum (molecular) & Cer-M & ND & $3467 \pm 732^{* *}$ \\
\hline Cerebellum (granule) & Cer-G & ND & ND \\
\hline
\end{tabular}

Values represent mean $\mathrm{dpm} / \mathrm{mg}$ tissue equivalent from four or five males in each species.

$* p<0.05$.

** $p<0.01$; comparing means by Student's $t$ test.

\section{Characteristics of ${ }^{125} I$-sarc-AVP binding}

To determine if ${ }^{125}$ I-sarc-AVP was binding to a similar receptor in the two species, $10 \mu \mathrm{m}$ sections through the laterodorsal thalamus for the prairie vole and lateral septum for the montane vole were compared in both saturation and competition studies. Although ${ }^{12} \mathrm{I}$-sarc-AVP was displaced by nanomolar concentrations of the selective $\mathrm{V}_{\mathrm{la}}$ antagonist $\mathrm{d}\left(\mathrm{CH}_{2}\right)_{5}[\operatorname{Tyr}(\mathrm{Me})] \mathrm{AVP}$ in both species $\left(\mathrm{IC}_{50}=8.8 \mathrm{nM}\right.$ for prairic volcs and $3.8 \mathrm{nM}$ for montane voles), neither species showed appreciable displacement of binding when sections were coincubated with Thr ${ }^{4}$ Gly ${ }^{7} \mathrm{OT}$ (OT specific) or [d $\left.\left(\mathrm{CH}_{2}\right)_{5}, \mathrm{D}-\mathrm{Phe}^{2}, \mathrm{Ile}^{4}, \mathrm{Ala}^{9}-\mathrm{NH}_{2}\right]-$ AVP $\left(V_{2}\right.$ specific) concentrations up to $1 \mu \mathrm{M}$ (Fig. $\left.5 A\right)$. This pharmacologic characterization resembles several previous reports of binding to AVP receptors in rat brain (see, e.g., Phillips et al., 1988; Shewey and Dorsa, 1988). Furthermore, exposing sections from both species to incremental concentration of ${ }^{125}$ [sarc-AVP resulted in a similar pattern of association with $50 \%$ of receptors occupied at $183.1 \mathrm{~nm}$ for prairie vole laterodorsal thalamus and $180.6 \mathrm{~nm}$ for montane vole lateral septum (Fig. $5 B)$.

\section{Phosphoinositol hydrolysis}

Phosphoinositol hydrolysis was examined in three regions for both prairie and montane voles (Table 3 ). In the montane vole septum, the induction of phosphoinositol increased $10.7 \pm 1.2 \%$ and $17.3 \pm 0.3 \%$ over baseline after 0.5 and $5.0 \mu \mathrm{g} \mathrm{AVP,} \mathrm{re-}$ spectively. In the prairie vole septum, AVP did not significantly increase phosphoinositol. Conversely, in the prairie vole thalamus, AVP increased phosphoinositol by $15.7 \pm 2.3 \%$, whereas no change was evident in the same region from the montane vole. In both species, AVP was ineffective at inducing phosphoinositol in the superior colliculus.

\section{Comparative studies}

If AVP receptor distribution were functionally related to social organization, a similar pattern should be evident in related species with analogous differences in behavior. Therefore, we next 
A.

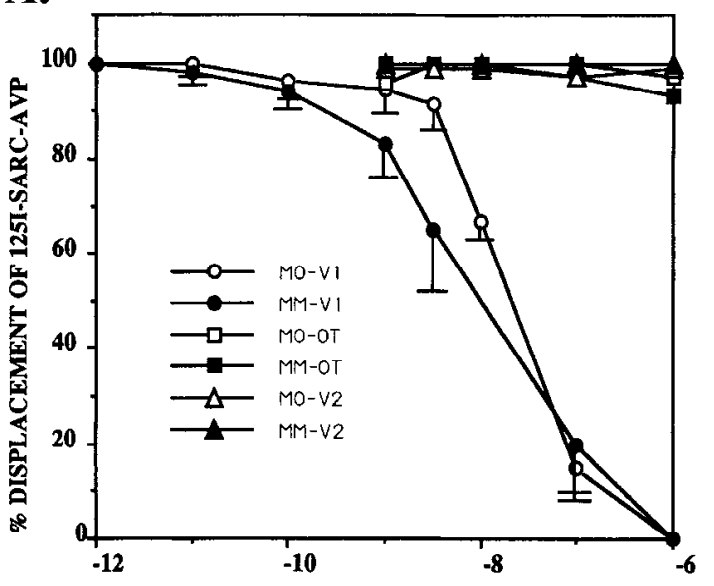

CONCENTRATION OF DISPLACER (M)
B.

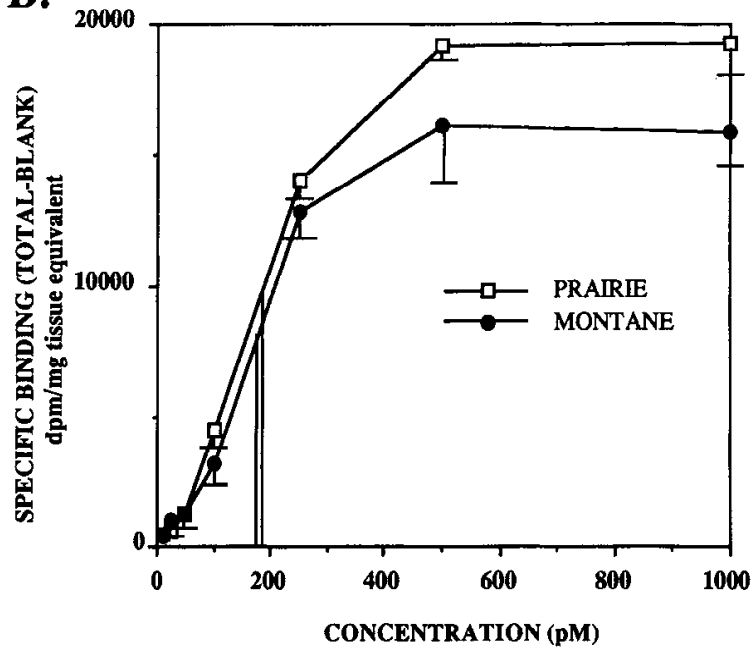

Figure 5. Competition and saturation studies with ${ }^{125} \mathrm{I}$-sarc-AVP. $A$, Sections through prairie laterodorsal thalamus and montane vole lateral septum were compared for their profiles of ${ }^{125} \mathrm{I}$-sarc-AVP displacement. In both species, ${ }^{125} \mathrm{I}$-sarc-AVP was displaced by the selective $\mathrm{V}_{1}$ ligand $\mathrm{d}\left(\mathrm{CH}_{2}\right)_{5}[\mathrm{Tyr}(\mathrm{Me})] \mathrm{AVP}$, with an $\mathrm{IC}_{50}$ in the low nanomolar range. Neither the oxytocin ligand $\mathrm{Thr}^{4} \mathrm{Gly}^{7} \mathrm{OT}$ or the $\mathrm{V}_{2}$ ligand $\left[\mathrm{d}\left(\mathrm{CH}_{2}\right)_{5}, \mathrm{D}-\mathrm{Phe}^{2}, \mathrm{Ile}^{4}, \mathrm{Ala}{ }^{9}-\right.$ $\mathrm{NH}_{2}$ ]-AVP showed appreciable displacement at concentrations up to $1 \mu \mathrm{M}$. Data are means from three studies in each species. $B$, Saturation curves obtained by incubating sections in incremental concentrations of ${ }^{125}$ I-sarc-AVP were compared in laterodorsal thalamus (prairie vole) and lateral septum (montane vole). Values represent specific binding after subtracting nonspecific binding [adjacent sections incubated in same concentration of ${ }^{125}$ I-sarc-AVP with $1 \mu \mathrm{M}$ of d($\left(\mathrm{CH}_{2}\right)_{5}$ [Tyr(Me)]AVP]. Point at which $50 \%$ of receptors are occupied appears nearly identical in two species. Data are means $( \pm$ SEM) from three experiments.

examined receptor distributions in two additional species of Microtus with similar (although not identical) behavioral differences, the monogamous pine vole ( $M$. pinetorum) (FitzGerald and Madison, 1983) and the promiscuous meadow vole $(M$. pennsylvanicus) (Madison, 1980). As with prairie and montane voles, ${ }^{125}$ I-sarc-AVP binding in the lateral septum was intense in the nonmonogamous species and relatively sparse in the monogamous species (meadow voles $=6298 \pm 1644$; pine voles $=708 \pm 184 \mathrm{dpm} / \mathrm{mg}$ tissue equivalent; $t(4)=3.38, p<0.03$ ) (Fig. 6). Meadow voles also showed more binding in the brainstem in the reticular nucleus, just at the region of the nucleus ambiguus, and in the hypoglossal nucleus (Fig. 6). Conversely, the most intense concentration of ${ }^{125}$ I-sarc-AVP binding in the pine vole brain began in the posterior division of the cingulate cortex and extended into retrosplenial cortex, where intense labeling was evident in layers I and III $(5741 \pm 946 \mathrm{dpm} / \mathrm{mg}$

\begin{tabular}{|c|c|c|}
\hline Region & Prairie vole & Montane vole \\
\hline \multicolumn{3}{|l|}{ Septum } \\
\hline $\operatorname{AVP}(0.5 \mu \mathrm{g})$ & $4.3 \pm 4.3$ & $10.7 \pm 1.2^{*}$ \\
\hline $\operatorname{AVP}(5.0 \mu \mathrm{g})$ & $10.0 \pm 6.1$ & $17.3 \pm 0.3^{*}$ \\
\hline \multicolumn{3}{|l|}{ Thalamus } \\
\hline $\operatorname{AVP}(0.5 \mu \mathrm{g})$ & ND & ND \\
\hline $\operatorname{AVP}(5.0 \mu \mathrm{g})$ & $15.7 \pm 2.3^{*}$ & $3.0 \pm 3.3$ \\
\hline \multicolumn{3}{|l|}{ Colliculus } \\
\hline $\operatorname{AVP}(0.5 \mu \mathrm{g})$ & ND & $4.5 \pm 4.5$ \\
\hline AVP $(5.0 \mu \mathrm{g})$ & ND & $1.5 \pm 1.5$ \\
\hline
\end{tabular}

Values represent means of three experiments (two for sup. coll.) with 10 animals of each species in each experiment. ND, not detectable (AVP values < buffer values).

${ }^{*} p<0.05$ compared to control (buffer). tissue equivalent). Specific binding was not detectable in this region in the meadow vole. These species also differed in the superior colliculus $(569 \pm 333$ vs $6010 \pm 1506$ in pine and meadow voles, respectively), but not in several other regions such as the diagonal band, thalamus, and dentate gyrus, where prairie and montane voles were found to show contrasting patterns of ${ }^{125}$ I-sarc-AVP binding.

\section{Discussion}

Based on previous behavioral studies, we hypothesized that central pathways for AVP would differ in closely related monogamous and nonmonogamous voles. The results demonstrate differences in the distribution of both ${ }^{3} \mathrm{H}$-AVP and ${ }^{125} \mathrm{I}$-sarcAVP binding in prairie and montane voles. These differences (1) appear to reflect local numbers of AVP receptors (based on competition and saturation data), (2) arc associated with regional differences in the functional response to AVP, and (3) are partially replicated in congeneric species. In a previous study, we demonstrated analogous species differences in the distribution of OT receptors (Insel and Shapiro, 1992). It does not appear that voles show unusual species variability in the expression of all membrane binding proteins, as comparative studies across four vole species found no differences in the distribution of $\mu$-opiate or benzodiazepine receptors (Insel and Shapiro, 1992). Differences in AVP receptor distribution are of particular interest because AVP has been recently implicated in the mediation of pair bonding and paternal behavior in the male prairie vole, essential aspects of monogamous social organization (Winslow et al., 1993; Wang et al., in press).

Several aspects of these binding studies require comment. First, the reader should note that certain regions showed considerable variability. In particular, the latcrodorsal and midline thalamic nuclei, labeled so clearly in the prairie vole with ${ }^{125} \mathrm{I}-$ sarc-AVP (Fig. 3), were labeled inconsistently. A few animals showed little detectable binding in these regions, even though 

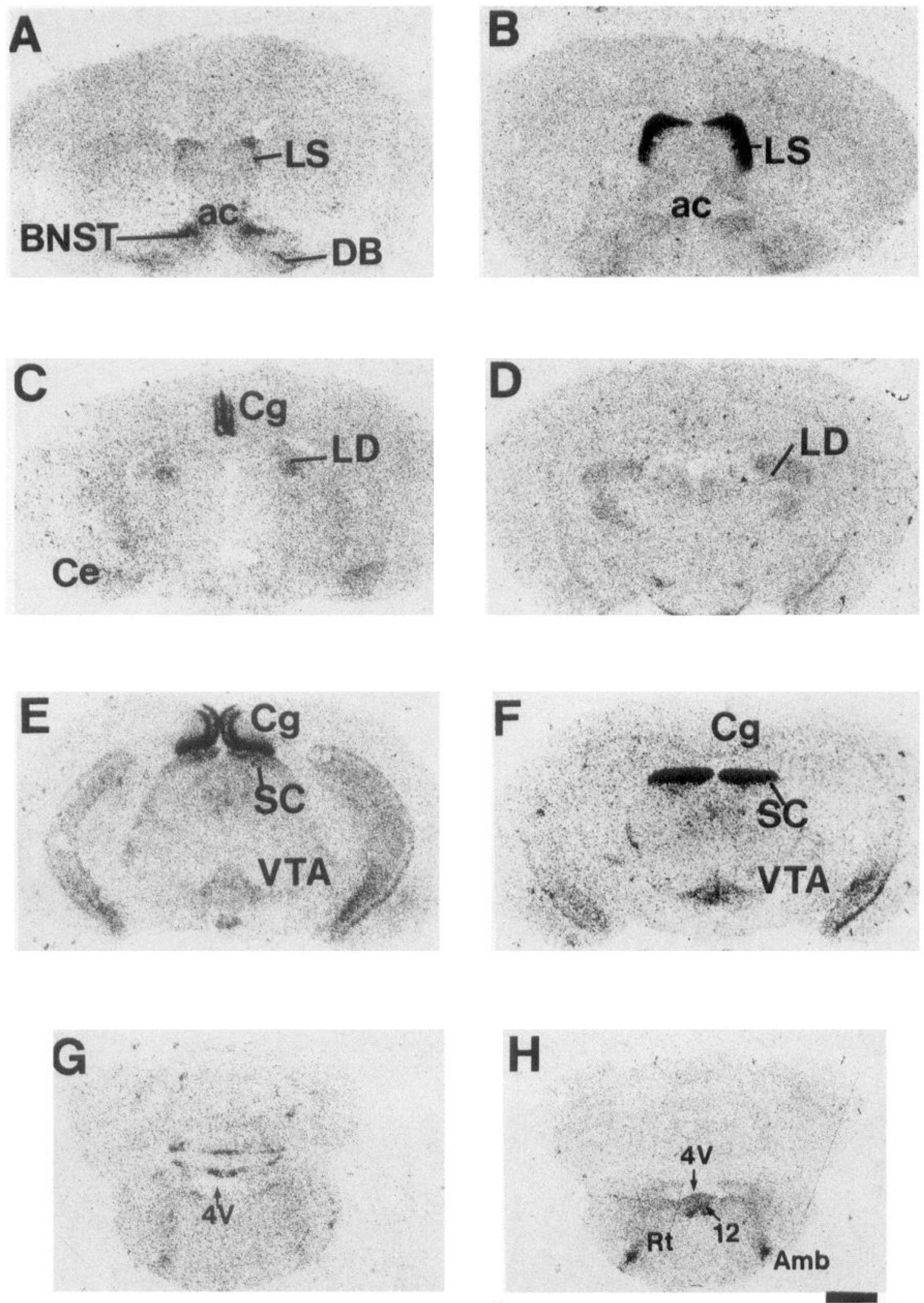

Figure 6. Binding of ${ }^{125} \mathrm{I}$-sarc-AVP in pine and meadow voles. To extend the species comparison to other voles selected for patterns of social organization, the pattern of ${ }^{125} \mathrm{I}$-sarc-AVP binding was compared in monogamous pine voles $(A, C, E$, and $G)$ and polygynous meadow voles $(B$, $D, F$, and $H$ ). Bright-field images shown here differ from the maps shown for prairie and montane voles (Fig. 3) except in the lateral septum, for which binding was low in pine vole and high in meadow vole. In the pine vole, ${ }^{125} \mathrm{I}$-sarc-AVP binding was particularly high in the posterior cingulate cortex, extending back into the retrosplenial cortex (here labeled $\mathrm{Cg}$ ), but conspicuously low in the superior colliculus ( $S C$ ). Binding was not detectable in the cingulate or retrosplenial cortex of the meadow vole, but was high in the superior colliculus (compare $E$ and $F$ ). ${ }^{125}$ I-sarc-AVP binding was also high in the hypoglossal nucleus $(12)$, the reticular nucleus $(R t)$, and nucleus ambiguus $(A m b)$ of the meadow vole, but not in the pine vole (compare panels $G$ and $H$ ). All abbreviations and quantitative values provided in Table 4 . Scale bar, $1.0 \mathrm{~mm}$. 


\begin{tabular}{|c|c|c|c|}
\hline Region & Abbrev. & Pine & Meadow \\
\hline \multicolumn{4}{|l|}{ Olfactory (main and accessory) } \\
\hline Internal granular layer & IGL & $340 \pm 131$ & $168 \pm 168$ \\
\hline External plex. layer & EPL & ND & ND \\
\hline Ant. olf. nucleus & AOP & ND & ND \\
\hline Vomeronasal nerve & VN & ND & ND \\
\hline Granule cell layer & $\mathrm{Gr}$ & $876 \pm 131$ & $497 \pm 287$ \\
\hline Accessory olf. bulb & $\mathrm{AOB}$ & $1270 \pm 146$ & $931 \pm 183$ \\
\hline \multicolumn{4}{|l|}{ Forebrain } \\
\hline Diagonal band & DB & $1747 \pm 367$ & $1292 \pm 613$ \\
\hline Nuc. accumbens & NAcc & ND & ND \\
\hline Latcral scptum & LS & $708 \pm 184$ & $6298 \pm 1644^{*}$ \\
\hline Bed nuc. of stria terminalis & BNST & $1829 \pm 375$ & $1220 \pm 288$ \\
\hline Cingulate cortex & $\mathrm{Cg}$ & $5741 \pm 946^{* *}$ & ND \\
\hline Ventral subiculum & VS & $1204 \pm 423$ & $674 \pm 168$ \\
\hline Dentate gyrus (post.) & DG & ND & ND \\
\hline Amygdala (central nuc.) & $\mathrm{Ce}$ & $284 \pm 151$ & $92 \pm 92$ \\
\hline Habenula (lateral) & $\mathbf{H}$ & ND & ND \\
\hline Thalamus (laterodorsal) & LD & $216 \pm 216$ & $1170 \pm 1092$ \\
\hline \multicolumn{4}{|l|}{ Midbrain } \\
\hline Superior colliculus & $\mathrm{SC}$ & $569 \pm 333$ & $6010 \pm 1506^{*}$ \\
\hline Ventral tegmental area & VTA & $412 \pm 232$ & $210 \pm 105$ \\
\hline
\end{tabular}

in these same brains ${ }^{125} \mathrm{I}$-sarc-AVP binding to other forebrain regions appeared unaffected. The reason for the variability in thalamic binding remains unclear at this time. In addition, binding to the central nucleus of the amygdala of the prairie vole, clearly detectable with ${ }^{3} \mathrm{H}$-AVP, was barely evident with ${ }^{125}$ Isarc-AVP. The difference may reflect the tendency of ${ }^{3} \mathrm{H}-\mathrm{AVP}$ to bind to both oxytocin and AVP receptors (Tribollet et al., 1988), as the central amygdala in the prairie vole is labeled by ${ }^{125}$ I-OTA, a selective oxytocin ligand (Witt et al., 1991; Insel and Shapiro, 1992). The alternative explanation, that ${ }^{225}$ I-sarcAVP binds to non-AVP receptors, seems less plausible as, consistent with previous studies (Phillips et al., 1988; Ferris et al., 1993), we found high selectivity for this ligand with as much as $93 \%$ displacement by a selective $V_{1}$ ligand and no evident displacement by a selective oxytocin agonist. Finally, the apparent absence of gender differences in either prairie or montane voles is surprising given the previously reported androgen-dependent behavioral responses to AVP (see above), the gender difference in AVP receptors in the golden hamster (Dubois-Dauphin et al., 1991), and the profound gender differences in the patterns of AVP innervation in the prairie vole (Bamshad et al., 1993).

Functional studies of second-messenger activation generally support the regional differences in ligand binding in that AVP induced phosphoinositol in the prairie vole thalamus and the montane vole septum. The magnitude of phosphoinositol induction in the septum was somewhat less than previous reports (Shewey and Dorsa, 1988; Poulin and Pittman, 1993b), probably due to the relatively small percentage of tissue with AVP receptors in each sample. In these studies, the need for large tissue volumes was offset by the importance of quickly delivering the tissue into an oxygenated buffer. We felt that the rapid dissection of 10 brains was the temporal limit for this method and 10 vole brains provided just enough tissue for three sets of triplicate tubes (two doses of AVP in addition to buffer). Therefore, we were unable to perform extensive dose-response studies to determine the optimal concentration of AVP for the induction of phosphoinositol. Nevertheless, a consistent increase in phosphoinositol could be detected in those regions with abundant ${ }^{125}$ I-sarc-AVP binding. The one conspicuous exception to this rule was the superior colliculus, which showed intense binding but no evidence of phosphoinositol induction. AVP receptors in this region may be coupled to a different effector system (Thibonnier, 1992) and thus play an important role in the processing of visual information. Even in the pine vole, which showed a relative absence of binding to the superior colliculus, there is a striking emergence of binding in the retrosplenial cortex-consistent with a role for AVP in the visual system. However, without positive data regarding cellular effects of AVP in either the superior colliculus or the retrosplenial region, one should be guarded about presuming any such function. Indeed, it seems equally plausible from our data that these binding sites are not functional but remain as an evolutionary vestige of the arginine-vasotocin (AVT) innervation of the visual system of the amphibian (Boyd et al., 1992), possibly related to the AVT receptor found in the avian optic tectum (Voorhuis et al., 1988).

What accounts for the species differences in receptor distribution? As noted above, these species do not differ in their distribution of two other neuroreceptors that have been examined, so the patterns with AVP and oxytocin cannot be attributed to some general species difference in chemical neuroanatomy. It seems possible that the species differences might reflect alterations in the selectivity for the ligand, but our competition data revealed similar patterns of displacement in both species, with both showing the expected pattern of $V_{1} \gg V_{2}$,OT. 
Although our rather primitive saturation experiments describe similar kinetics in prairie vole thalamus and montane vole lateral septum, these experiments do not rule out the possibility that (1) ${ }^{125}$ I-sarc-AVP is binding to different receptors in the two species or (2) ${ }^{125}$ I-sarc-AVP is binding to a family of receptors with variable species expression. We hope that current attempts to clone the cDNAs for these receptors in these different species will provide some clarity on each of these possibilities. We have also entertained the possibility that there is only a single $V_{1}$ receptor across these various species, but that species differences in either genomic DNA regulatory elements or local transcription factors lead to the observed patterns of regional expression.

As prairie voles show pair bonding and paternal behavior and montane voles do not, which of the receptor fields in the prairie vole are likely to be responsible for these important species differences in behavior? The most consistent species differences across the four species was the increased binding in the lateral septum of the nonmonogamous voles relative to the monogamous voles. Several lines of evidence suggest the importance of this region for AVP's bchavioral cffects. AVP facilitates social memory in rats (Dantzer et al., 1988), flank marking in hamsters (Irvin et al., 1990), and paternal behavior in prairie voles (Wang et al., in press) following microinjection into the lateral septum. Moreover, AVP appears to have both excitatory effects and to induce long-term potentiation in rat lateral septum slices in vitro (van den Hooff et al., 1989; Van den Hooff and Urban, 1990). The vasopressinergic innervation of the lateral septum has been shown to be sexually dimorphic in the rat (De Vries et al., 1985) and the prairie vole (Bamshad et al., 1993) and to be associated with both aggressive behavior (Compaan et al., 1993) and paternal care (Bamshad et al., 1993). As territorial defense and paternal care are critical aspects of monogamous social organization, one would predict that monogamous males should show intense AVP receptor binding in the lateral septum. Contrary to this prediction, we found few AVP receptors in the lateral septum from prairic and pine voles, the two monogamous species. The reduced functional response to AVP in the prairie vole septum, relative to the montane vole septum, further underscores this paradox.

We do not have a simple explanation for the apparent paucity of AVP receptors in the prairie vole lateral septum but we have one additional observation that may resolve this problem. Sexually naive prairie voles (used in the present study) do not respond to centrally administered AVP with an increase in aggression unless (1) AVP is given chronically via a minipump or (2) the vole is given extensive mating experience (believed to release AVP into the lateral septum) (J. Winslow and T. Insel, unpublished observations). As AVP administration has been shown recently to sensitize the lateral septum to subsequent AVP (as measured by the induction of phosphoinositol) (Poulin and Pittman, 1993a), it seems plausible that the AVP receptors in the lateral septum of the sexually naive prairie (and pine) vole are immature until after mating when the repeated release of endogenous AVP facilitates the coupling of the receptor to intracellular second-messenger systems. Unfortunately, this hypothesis does not explain why montane voles, which are less territorial and less paternal, show a rich expression of functionally coupled AVP receptors in the naive state. If montane and meadow voles lack the AVP innervation of the lateral septum that is so prominent in male (but not female) prairie voles or if AVP is not released in these species in response to mating or pup stimuli, then the abundance of receptors in this region will not subserve pair bonding or paternal behavior. We are currently investigating these possibilities with comparative studies of AVP projections in these same four species.

Comparative studies are by their very nature correlational. Nevertheless, these kinds of studies in conjunction with experimental studies using selective agonists and antagonists provide a converging picture of AVP as an important mediator of social signals for males. How does AVP release translate into complex behaviors such as pair bonding and paternal care? The present results can only begin to answer this question by suggesting the likely targets for AVP's central effects in monogamous males. The next step will require a careful analysis of what aspects of these complex behaviors are affected by AVP. In other species, there are convincing data for AVP effects on social recognition, regulation of body temperature (possibly promoting huddling and nest building), and responses to social separation (reviewed in de Wied et al., 1993). The intense binding evident in the accessory olfactory system suggests that AVP could also modulate the processing of vomeronasal signals. Receptors in the thalamus may modulate information flow from brainstem projections through relay nuclei. Further research will be necessary to link the species-specific patterns of receptors shown here to discrete aspects of behavioral responses.

\section{References}

Bamshad M, Novak M, de Vries G (1993) Sex and species differences in the vasopressin innervation of scxually naive and parental prairie voles, Microtus ochrogaster and meadow voles, Microtus pennsylvanicus. J Neuroendocrinol 5:247-256.

Bluthe R-M, Schoenen J, Dantzer R (1990) Androgen-dependent vasopressinergic neurons are involved in social recognition in rats. Brain Res 519:150-157.

Boyd S, Tyler C, De Vries G (1992) Sexual dimorphism in the vasotocin system of the bullfrog (Rana catesbeiana). J Comp Neurol 325:313-325.

Carter CS, Williams JR, Witt DM (1990) The biology of social bonding in a monogamous mammal. In: Hormones, brain and behavior in vertebrates, 2 , Behavioral activation in males and females-social interactions and reproductive endocrinology (Balthazart $\mathrm{J}$, ed). Basel: Karger.

Compaan JC, Buijs RM, Pool CW, de Ruitcr AJH, Koolhaas JM (1993) Differential lateral septal vasopressin in aggressive and nonaggressive mice. Brain Res Bull 30:1-6.

Dantzer R, Bluthe R, Koob G, Le Moal M (1987) Modulation of social memory in male rats by neurohypophyseal peptides. Psychopharmacology 91:363-368.

Dantzer R, Koob G, Bluthe R, Le Moal M (1988) Septal vasopressin modulates social memory in male rats. Brain Res 457:143-147.

De Vries GJ, Buijs RM, Van Leeuwen FW, Caffe AR, Swaab DF (1985) The vasopressinergic innervation of the brain in normal and castrated rats. J Comp Neurol 233:236-254.

de Wied D, Diamant M, Fodor M (1993) Central nervous system effects of the neurohypophyseal hormones and related peptides. Front Neuroendocrinol 14:251-302.

Dewsbury DA (1981) An exercise in the prediction of monogamy in the field from laboratory data on 42 species of muroid rodents. Biologist 63:138-162.

Dubois-Dauphin M, Pevet P, Tribollet E, Dreifuss JJ (1990) Vasopressin in the brain of the golden hamster: the distribution of vasopressin binding sites and of immunoreactivity to the vasopressinrelated glycopeptide. J Comp Neurol 300:535-548.

Dubois-Dauphin M, Theler J-M, Zaganidis N, Dominik W, Tribollet E, Pevet P, Charpak G, Dreifuss J (1991) Expression of vasopressin receptors in hamster hypothalamus is sexually dimorphic and dependent on photoperiod. Proc Natl Acad Sci USA 88:11163-11167.

Ferris C (1992) Role of vasopressin in aggressive and dominant/subordinate behaviors. In: Oxytocin in maternal, sexual, and social behaviors (Pedersen C, Caldwell J, Jirikowski G, Insel T, eds), pp 212 227. New York: New York Academy of Sciences.

Ferris C, Albers H, Wesolowski S, Goldman B, Leeman S (1984) Va- 
sopressin injected into the hypothalamus triggers a stereotypic behavior in Golden hamsters. Science 224:521-523.

Ferris C, Delville Y, Grzonka Z, Insel T (1993) An iodinated vasopressin (V1) antagonist blocks flank marking and selectively labels neural binding sites in golden hamsters. Physiol Behav

FitzGerald RW, Madison DM (1983) Social organization of a freeranging population of pine voles. Behav Ecol Sociobiol 13:183-187.

Getz LL, Hofman JE (1986) Social organization in free living prairie voles, Microtus ochrogaster.

Getz LL, Carter CS, Gavish L (1981) The mating system of the prairie vole Microtus ochrogaster: field and laboratory evidence for pair bonding. Behav Ecol Sociobiol 8:189-194.

Insel T, Shapiro L (1992) Oxytocin receptor distribution reflects social organization in monogamous and polygamous voles. Proc Natl Acad Sci USA 89:5981-5985.

Irvin R, Szot P, Dorsa D, Potegal M, Ferris C (1990) Vasopressin in the septal area of the golden hamster controls scent marking and grooming. Physiol Behav 48:693-699.

Jannett FJ (1980) Social dynamics in the montane vole Microtus montanus as a paradigm. Biologist 62:3-19.

Kruszynski M, Lammek B, Manning M, Seto J, Haldar J, Sawyer WH (1980) (1- $\beta$-Mercapto- $\beta, \beta$-cyclopentamethylenepropionic acid), $2-(O$ methyl)tyrosine)arginine-vasopressin and (1-( $\beta$-mercapto- $\beta, \beta$-cyclopentamethylenepropionic acid)) arginine-vasopressin, two highly potent antagonists of the vasopressor response to arginine-vasopressin. J Med Chem 23:364-368.

Madison DM (1980) Space use and social structure in meadow voles. Behav Ecol Sociobiol 7:65-71.

McGuire B, Novak M (1986) Parental care and its relation to social organization in the montane vole. J Mammol 67:305-311.

Oliveras D, Novak M (1986) A comparison of paternal behaviour in the meadow vole, prairie vole, and pine vole. Anim Behav 34:519526.

Paxinos G, Watson C (1986) The rat brain in stereotaxic coordinates, 2d ed. San Diego: Academic.

Phillips P, Abrahams J, Kelly J, Paxinos G, Grzonka Z, Mendelsohn $F$, Johnston C (1988) Localization of vasopressin binding sites in rat brain by in vitro autoradiography using a radioiodinated V1 receptor antagonist. Neuroscience 27:749-761.

Poulin P, Pittman Q (1993a) Arginine vasopressin (AVP)-induced sensitization in brain: facilitated inositol phosphate production without changes in receptor number. J Neuroendocrinol 5:23-31.

Poulin P, Pittman O (1993b) Oxytocin pretreatment enhances arginine vasopressin-induced motor disturbances and arginine vasopressininduced phosphoinositol hydrolysis in rat septum: a cross-sensitization phenomenon. J Neuroendocrinol 5:33-39.

Shapiro LE, Dewsbury DA (1990) Differences in affiliative behavior, pair bonding, and vaginal cytology in two species of vole. J Comp Psychol 104:268-274.

Shapiro LE, Insel TR (1990) Infant's response to social separation reflects adult differences in affiliative behavior: a comparative developmental study in prairie and montane voles. Dev Psychobiol 23: 375-394.

Shewey L, Dorsa D (1988) V1-type vasopressin receptors in rat brain septum: binding characteristics and effects on inositol phospholipid metabolism. J Neurosci 8:1671-1677.

Thibonnier M (1992) Signal transduction of V1-vascular vasopressin receptors. Reg Pept 38:1-11.

Tribollet E, Barberis C, Jard S, Dubois-Dauphin M, Dreifuss JJ (1988) Localization and pharmacological characterization of high affinity binding sites for vasopressin and oxytocin in the rat brain by light microscopic autoradiography. Brain Res 442:105-118.

Tribollet E, Audigier S, Dubois-Dauphin M, Dreifuss JJ (1992) Localization and characterization of binding sites for vasopressin and oxytocin in the brain of the guinea pig. Brain Res 589 .

Van den Hooff P, Urban I (1990) Vasopressin potentiates excitatory transmission in slices of the rat dorso-lateral septum. Synapse 5:201206.

van den Hooff P, Urban IJA, de Wied D (1989) Vasopressin maintains long-term potentiation in rat lateral septum slices. Brain Res 505 : 181-186

Voorhuis TAM, de Kloet ER, de Wied D (1988) The distribution and plasticity of $\left[{ }^{3} \mathrm{H}\right]$ vasopressin-labeled specific binding sites in the canary brain. Brain Res 457:148-153.

Wang Z, Ferris C, De Vries G (in press) Role of septal vasopressin innervation in paternal behavior in prairie voles (Microtus ochrogaster). Proc Natl Acad Sci USA, in press.

Williams J, Insel TR, Harbaugh CR, Carter CS (in press) Oxytocin administered centrally facilitates formation of a partner preference in the monogamous female prairie vole. J Neuroendocrinol, in press.

Winslow J, Insel T (1991a) Vasopressin modulates male squirrel monkeys behavior during social separation. Eur J Pharmacol 200:95-101.

Winslow JT, Insel TR (1991b) Social status in pairs of male squirrel monkeys determines response to central oxytocin administration. J Neurosci 11:2032-2038.

Winslow J, Insel T (1993) Effects of central vasopressin administration to infant rats. Eur J Pharmacol 233:101-107.

Winslow J, Hastings N, Carter C, Harbaugh C, Insel T (1993) A role for central vasopressin in pair bonding in monogamous prairie voles. Nature 365:545-548.

Witt DM, Carter CS, Insel TR (1991) Oxytocin receptor binding in female prairie voles: endogenous and exogenous estradiol stimulation. J Neuroendocrinol 3:155-161. 